\title{
Lumen
}

Selected Proceedings from the Canadian Society for Eighteenth-Century Studies

\section{Dismantling Moral Superstructures: Aubin's Subversion of Ideological Insularity in The Life of Madam de Beaumount}

\section{Katherine E. Zelinsky}

Volume 12, 1993

URI : https://id.erudit.org/iderudit/1012576ar

DOI : https://doi.org/10.7202/1012576ar

Aller au sommaire du numéro

Éditeur(s)

Canadian Society for Eighteenth-Century Studies / Société canadienne d'étude du dix-huitième siècle

ISSN

1209-3696 (imprimé)

1927-8284 (numérique)

Découvrir la revue

Citer cet article

Zelinsky, K. E. (1993). Dismantling Moral Superstructures: Aubin's Subversion of Ideological Insularity in The Life of Madam de Beaumount. Lumen, 12, 27-34. https://doi.org/10.7202/1012576ar

Copyright (c) Canadian Society for Eighteenth-Century Studies / Sociéte canadienne d'étude du dix-huitième siècle, 1993
Ce document est protégé par la loi sur le droit d'auteur. L'utilisation des services d'Érudit (y compris la reproduction) est assujettie à sa politique d'utilisation que vous pouvez consulter en ligne.

https://apropos.erudit.org/fr/usagers/politique-dutilisation/ 


\section{Dismantling Moral Superstructures: Aubin's Subversion of Ideological Insularity in The Life of Madam de Beaumount}

In the closing sentence of The Life of Madam de Beaumount, Penelope Aubin's pious narrative persona exhorts her readers to 'imitate [the virtues of her worthy characters], since that is the ... most certain and noble Method to perpetuate our Names, and render our Memories immortal' (143). There is a certain proleptic irony in this devotional plea with its urge toward immortality and posterity. Recent critical interest in the revival of early eighteenth-century women writers has reminded us of the extent to which the selective process of canonization has defined the limits of our cultural memory. Yet selective processes persist. As Behn, Manley, and Haywood pervade increasingly more critical space, Aubin retains her marginal position as literary wallflower. Cast as the demure and unquestioning Christian moralist, she has perhaps suffered as much from the attention of her small group of admirers as she has struggled against complete oblivion. Despite their recognition of Aubin's contributions to the history of the novel, John Richetti and Jane Spencer, for example, have done little to suggest new theoretical and methodological approaches to her fiction. Instead, their well-intended tributes to the novelist as 'moral censor of the age' (Richetti 229) and a 'proper woman writer' (Spencer 86) have simply reinforced the narrow conceptual boundaries of the Aubin critical canon. ${ }^{1}$

Perhaps the greatest disservice to Aubin has been the critical tendency either to repress or to reconcile problematic narrative features. William McBurney's parenthetical observation that her last two novels 'show the effect of the particular temptation of excessive and unintegrated variety' (256) may be the most provocative commentary on Aubin's fiction offered thus far, providing pertinent insight into her geographically and generically various early novels as well. McBurney's successors, however, have reacted somewhat defensively to the charge. Richetti in particular responds with the argument that 'the unity which [Aubin's] homiletic purpose seeks thrives on a disorderly succession of calamities 
through which the providence of God and the virtue of her heroes can shine' (228). Josephine Grieder and Jane Spencer likewise praise Aubin's ability to integrate dramatic and didactic elements. ${ }^{2}$ While this virtually unbroken consensus demonstrates the enduring and persuasive power of critical reception, it also attests to the proficiency with which Aubin masks incongruities and irregularities underlying her smooth orthodox surfaces. Aubin's subversive sophistication may be no more evident than in her insurgent Life of Madam de Beaumount which, while it expounds the passive morality of triumphant virtue and resignation to Providence, accordingly demonstrates its failure to address complex moral issues and to accommodate multifarious human experience in an increasingly cosmopolitan and secularized world. Replete with images of enclosure and confinement in the form of caves, convents and castles, the novel simultaneously demonstrates the dangers, as well as the virtual impossibility, of geographical insularity and isolation. It is, for example, the idyllic, secluded Welsh countryside extolled by the narrator wherein Belinda is threatened with rape by the amphibious former country-dweller turned 'lustful Londoner' (102) and wherein Lisbia and Magdalena, her less fortunate though apparently also virtuous female companions, are taken by force by the same group of refugee English banditti from whom she is forced to flee. And it is accordingly within this isolated but also vulnerable and varied fictional landscape that Aubin unmasks the gender-based contradictions, inconsistencies, and inequities underlying the shallow morality of innocence rewarded.

Aubin's Preface immediately announces its preoccupation with space and boundaries as the narrator deplores the madness of the English in having 'exceeded the French in extravagant Whimseys, ... grown false as Jews in Trading, ... and [acquired] more Religions ... than the Dutch' (vi). This initial xenophobic anxiety soon gives way to poised consolation in the assurance of geographical and moral insularity in Wales, being a Place not extremely populous ... [and] more rich in Virtue than England, which is now improved in Vice only, and rich in Foreigners' (vii). Narrative movement from the racial chaos of England to the order and isolation of Wales culminates in the most constricted of the novel's spatial metaphors, the cave-a 'bower of [female] virtue' (Richetti 221) for which Wales provides an analogy: 'He that would keep his Integrity, must dwell in a Cell; and Belinda had never been so virtuous, had she not been bred in a Cave' (vii). The controlled movement from heterogeneous space to womb-like cave provides a spatial paradigm for the narrator's desire to return to a pre-capitalist, paternalistic, Christian order in which the sacred space of English boundaries stood inviolable against the profane 'chaotic space, peopled by ... 'foreigners" (29). ${ }^{3}$ That such an order is itself the locus of ideological chaos and contradiction is 
implicit in the narrative's problematic rhetorical and structural procedures. Analogies, for example, suggest difference as much as likeness, as the English too, by virtue of their previous claim to moral superiority, are distinguished from the morally-depraved and contaminative foreigners. Conversely, polarities comprise common as well as disparate elements, and the antithesis between England and Wales is eventually reconciled in the narrator's equal regard for the 'true-born English' (viii) and the loyal and brave Welsh. Analogies and polarities thereby both unite and divide, contesting by means of their internally chaotic structures the clear moral categories of good and evil, virtue and vice, which support the narratives's illusion of ideological and structural coherence.

Contradiction initiates the narrative proper with Lluelling's entry in to the heroines' cave, an ambiguous site of female autonomy and vulnerability, a refuge from and a model of civilization, complete with imported French furnishings and an elaborate skylight. Like the cave itself, Madam de Beaumount's interpolated tale is a composite of paradox and inconsistency. A story about filial loyalty and moral integrity, the narrative is a testimonial of heroic female defiance. Madam de Beaumount's refusal to abandon her mother's religion, in opposition to the dictates of her tyrannical father-in-law, provides the impetus behind the novel's action and seems to promise a feminist celebration of transgression. But beneath the story's libertarian surface lie insidious prohibitions against both the act and expression of female rebellion. The limits of female freedom and heroinism are clearly circumscribed. Madam de Beaumount can defy patriarchal tyranny only by sacrificing husband and home, just as she can escape subsequent imprisonment only through the heroic intervention of men. The discourse of female power and initiative is similarly contained and attenuated by means of the tale's moral superstructure, which provides a religious frame of reference for the interpretation of the heroine's trials. While the narrative appears to endorse the violation of gender boundaries in its appropriation of male tropes and conventions (defiance, travel, adventure), structural transgressions ultimately accede to ideological demands, as the story ends with a homiletic affirmation of Christian resignation. Passivity and submission displace struggle and defiance, comprising the 'great Truth' of the heroine's homiletic set-piece, that 'we have nothing more to do ... but to resign our Wills to the Divine Being' (45).

Whereas the underlying ideology of Christian resignation undercuts the transgressive surface in Madam de Beaumount's narrative, Christian submission to the will of God provides the surface overlay undermined by a transgressive substructure in the Marquis de Beaumont's story. Superficially, though, the narratives act as homologous, extended variations on a theme, exemplifying the novel's Christian metaphysic. In the 
interests of ideological coherence, male and female experience is homogenized: gender polarities are veiled and diffused by the novel's overriding discourse of gender-neutral Christian struggle and endurance. The marquis's story bears ostensible resemblances to his wife's in its defiance of paternal authority and in its consequent series of confinements and trials of faith. Unlike his victimized female counterpart, however, the hero is invested with the power of aggressive and transgressive action, to which is added complete moral immunity. When he is confined in 'an old Tower on the Borders of Muscovy' (82-83), rather than invoking the assistance of Providence, as did his imprisoned wife, he and a fellow prisoner resolve to 'kill [their] Gaoler, and fight [their] way out' (83). Later captured by banditti, de Beaumount accepts their offer of increased freedom and resorts for a time to theft. However, his recourse to murder and theft is overshadowed by his exemplary capacity to resist sexual temptation out of fidelity to his wife. Ignoring murder and theft, the Preface praises de Beaumont for having 'loved an absent Wife so well, that he obstinately refused a pretty Lady a Favour' (vii).

Despite the narrative's efforts to repress the hero's violation of central Christian precepts, diversionary strategies betray themselves, exposing the novel's gender-proscribed boundaries of transgression and the gender-based underpinnings of Christian belief. Murder, for example, is apparently exonerable when simple male freedom is imperilled, as there is no extenuating textual evidence that the marquis's act of violence is motivated by self-defense. Prohibitions against female acts of retaliation, however, are considerably less flexible, and the defensive options available to female victims considerably less varied, than those expected of males. When, for instance, the perfidious Glandore threatens Belinda with rape, she responds in gender-prescribed verbal form, confronted as she is by a man holding a pistol and assisted by an accomplice. Even the conventionality of her rhetoric testifies to the limited responsesphysical and verbal-which propriety-bound, bourgeois Christianity deems appropriate to female victims: 'By Heaven, I'll never give Consent, and if you force me like a Brute, ... I shall then hate and scorn you ...; nay, you shall drag me sooner to my Grave, than to your Bed' (62). The moral imperative that women ought to sacrifice their lives in order to prohibit the act or to prevent the repetition of rape finds perhaps its most vocal proponent in the novel's prototypical moral authority, the 'genteel' (10) Lluelling, who discards even the pretense of propriety in his impatience to discover whether Belinda's wasted and bedraggled body has been 'polluted with [some vile Ravisher's] curs'd Embraces' (128). Propriety, conversely, clearly defines the limits of Belinda's response; even her 'disdain' (128) is stylized, defiant yet constrained and contained by the ideology that demands self-justification while simulta- 
neously offering the assurance of inviolable virtue: 'can you believe me capable of so vile, so base a Crime ...? No; I would have prefer'd the cruellest Death to Infamy' (128). Belinda's confusion of rape victim with criminal reflects not only the ideological confusion inherent in the myth of virtue rewarded but also the hypocrisy with which Christian doctrine makes claims to gender neutrality in addressing questions of victimization and culpability.

The question of female culpability in fact underlies Madam de Beaumount's initial act of defiance, which affords a veiled analogue for the myth of the Fall. Although disobedience towards the father ultimately achieves vindication in the closure of virtue rewarded, the novel'simplicit incrimination of woman as source of evil is perhaps most apparent in closure itself, evocative as it is of the hermetic Eden that romantically negates suffering and victimization. Recourse to myth thus exposes the illusion of narrative resolution, unveiling the novel's intransigent source of contradiction - the myth of Eve, the mother behind the mother. Suppressed like the narrative's misogynistic substructure, Madam de Beaumount's mother is a virtual abstraction; denied dramatic representation, she is a ghostlike and muted yet culpable instigator of chaos. Her transgressions are, however, equally abstract, suggested yet simultaneously denied by textual inconsistencies and ambiguities. Her implicit disobedience of her Catholic husband in secretly educating their daughter in the Protestant faith provides a case in point, since her covert defiance appears, at the same time, to have neither eluded her husband's discovery nor met with his complete disapproval. While he entrusts his orphaned daughter to the care of Catholic noblemen prior to his death, he nonetheless enjoins them 'never [to] force [her] inclinations in any thing, or force [her] into a Convent' (21). ${ }^{4}$ Apparently, too, Madam de Beaumount's maternal grandfather, even more ghostlike, was also a Protestant and likely influential in his daughter's act of wifely insubordination. If, in the welter of conflicting details, the implication of disobedience appears dubious, textual equivocation similarly characterizes Lluelling's accusation of the mother for the death of his father, who, he claims, died of unrequited love soon after her departure from England to France. Lluelling also admits, however, that his father 'left [him] an orphan about three Years old' (42) and that this is the 'melancholy Account [he has] had of his Death' (42). Moreover, Madam de Beaumount has indicated, before Lluelling divulges the connection between her mother and his father, that her mother went to France for political reasons, accompanying her father and 'the unfortunate Queen of England ... to whom [her] Mother's Father was a loyal, and faithful Servant, tho a Protestant' (20).

But the most compelling indication of the chimerical nature of Lluelling's accusation consists in the novel's gender-determined re- 
sponses to unrequited love. Whereas the narrative's male protagonists make vociferous threats about dying of rejection, only the females transform discourse into action. Lluelling's suicide threats are, indeed, remarkably short-lived; apparently, histrionics are superfluous in convincing the credulous Belinda to avoid repeating her grandmother's crime. The stoical marquis also considers self-destruction after the rejected Zara poisons herself, but despair finds immediate relief in his recollection of Christian injunctions against suicide. Notwithstanding his rigid adherence to Christian precept, however, the morally scrupulous marquis can apparently reconcile his strict observance of prohibitions against suicide with his comparatively lax observance of prohibitions against murder. Indeed, if Madam de Beaumount's mother can be accused of killing Lluelling's spurned father, then the marquis is certainly, on the same grounds, culpable for the deaths of the rejected Zara and his second wife. Yet his culpability brings relief rather than compunction: his second wife's death is in fact a timely godsend that spares him the agony of moral dilemma. As he later explains to Madam de Beaumount, 'the Lady was so happy as to die before I was bless'd with the knowledge of your Safety' (104).

Though 'happy' can suggest either felicity or opportune timing, the happiness the marquis attributes to his dying wife is unequivocal. According to his recollection of her dying words, a recollection that conveniently serves to absolve him of all responsibility for her death, it was with a martyr-like 'Pleasure' that she '[left] the World' in order to 'set [him] free' (93). Rather curiously, unlike the momentarily suicidal marquis, the lady, also a Christian, appears to be able to reconcile suicidal resignation with religious belief. That the marquis and even her priest seem likewise oblivious to the transgressive nature of her death suggests that, where romance and religious conventions operate concurrently, female suicide is only nominally a transgressive or a tragic act. Deference to stringent prohibitions against martyrdom may be morally imperative for men, but female self-sacrifice appears to be wholly in keeping with both romance ideology, which expects women to die of unrequited love, and Christian ideology, which directs women to forfeit their lives to preserve their chastity. At the same time, however, the precise cause of the lady's death remains unclear. Like Lluelling's father, whom Lluelling absolves of all agency by attributing responsibility for his death to his alleged spurner, the lady dies of unrequited love and is hence, by means of the same logic, victim rather than culpable agent. But, unlike the guilty spurner of Lluelling's father, the marquis remains entirely blameless. Evidently having inherited both the guilt and guise of her mother, Madam de Beaumount, in the form of a ghost, bears implicit responsibility for the deaths of both women. Apparently this 
demonic apparition not only prohibited the marquis from marrying Zara by making his 'Heart ... a Captive' (79) to her memory, but also frightened him into impotence during his marriage to his second wife. His account is equivocal-self-exculpatory in its suggestions of heightened sensibility and unwavering loyalty, accusatory in its imputation of ghostly aggression and retribution: 'I never enter'd any Bed with this Lady, but I shiver'd ... I fancy'd Belinda's Ghost pursued me' (92). Little wonder that before she dies, Zara expresses the vengeful desire to 'seek the Ghost of her that murders me' (81).

Apparitions, equivocations, contradictions: the materials out of which the novel is formed appear to be the elements which Aubin likewise saw as comprising both Christian myth and eighteenth-century Christian (Catholic as well as Protestant) doctrine and practice. Fissured and factious, imbued with the rhetoric of male romance conventions, preoccupied with female propriety, and undergirded by male power and hegemony, the ideology of rewarded virtue and submission to Providence promulgated by the pious narrator is, for Aubin, an elaborate façade for imperialist and patriarchal oppression. Although muffled by the stridently self-assured persona of the 'self-righteous' polemicist (Richetti 231), beneath the narrator's confident proclamations of moral certitude and unconflicted faith, Aubin speaks from the position of the marginalized. Indeed, as both an English Catholic (though, it appears by virtue of her gender, a highly disillusioned and skeptical one) and a woman, Aubin was also the 'Other,' the victim behind exclusionary, insular imperialist and patriarchal ideologies. For over two hundred years the voice of the marginalized Aubin has, for critics at least, remained muffled beneath her sermonizing conservative persona. In view of the encouraging efforts of recent critics of the eighteenth-century toward expanding literary boundaries, it is certainly time to reassess Aubin's contributions to literary history. Her possible influence, for example, on such works as Elizabeth Inchbald's A Simple Story and Frances Burney's Cecilia and Camilla, all of which expose the gender-biased nature of moral and social prohibitions, as well as the restrictions placed on female space and behaviour, provides a rich area for critical exploration. Ultimately, though, Aubin's revival depends on our ability to see beneath and behind the conservative mask that has for so long concealed her complexity and imperilled her fame.

KATHERINE E. ZELINSKY

University of Calgary 


\section{Notes}

1 Richetti entitles his chapter on Aubin, Barker and Rowe "The Novel as Pious Polemic.'

2 Grieder expresses some concerns about Aubin's 'priggish' heroes in both The Life of Madam de Beaumount and The Strange Adventures of the Count de Vinevil but concludes that Aubin 'succeeds in mixing drama and moralizing as well as she mixes instruction and delight' (10).

3 Eliade argues that 'one of the outstanding characteristics of traditional societies is the opposition that they assume between their inhabited territory and the unknown and indeterminate space that surrounds it. The former is the world ... everything outside it is ... a sort of 'other world,' a foreign, chaotic space, peopled by ghosts, demons, 'foreigners"' (29).

4 Plot and thematic resemblances between The Life of Madam de Beaumount and Elizabeth Inchbald's $A$ Simple Story are striking. Inchbald's Miss Milner is, like her mother, educated in the Protestant faith. Before his death, Mr Milner, a Catholic, leaves his daughter in the care of the Catholic priest, Dorriforth, but 'restrain[s] him from all authority to direct his ward in one religious opinion contrary to those her mother had professed' (5). Despite paternal injunctions, both Madam de Beaumount and Miss Milner become victims of religious oppression at the hands of their guardians and other male authority figures.

\section{Works Cited}

Aubin, Penelope. The Life of Madam de Beaumount, a French Lady and The Strange Adventures of Count de Vinevil and His Family. 1721. Int. Josephine Grieder. Foundations of the Novel. New York: Garland, 1973.

Eliade, Mircea. The Sacred and the Profane: The Nature of Religion. Trans. Willard R. Trask. New York: Harcourt, 1959.

Grieder, Josephine. Introduction. Aubin 5-11.

Inchbald, Elizabeth. A Simple Story. 1791. Ed. J. M. S. Tomkins. London: Oxford UP, 1967.

McBurney, William H. 'Mrs. Penelope Aubin and the Early Eighteenth-Century English Novel.' Huntington Library Quarterly 20 (1957): 245-67.

Richetti, John J. Popular Fiction Before Richardson: Narrative Patterns 1700-1739. Oxford: Clarendon, 1969.

Spencer, Jane. The Rise of the Woman Novelist: From Aphra Behn to Jane Austen. Oxford: Blackwell, 1986. 